CURRENT ECONOMIC ISSUES - BKR

\title{
Financial Systems, Financial Governance And Economic Development ${ }^{*}$
}

Jan Kregel ${ }^{\dagger}$

In his General Theory Keynes (1936) identified "The outstanding faults of the economic society in which we live are its failure to provide for full employment and its arbitrary and inequitable distribution of wealth and incomes."(1936: 372) He traced these faults to the behavior of the financial system: wealth holders' irrational demand for liquidity in the face of uncertainty about the value of their investments, and the failure of the financial system to satisfy this irrational demand for liquidity when necessary. For Keynes scarcity was not the result of insufficient resources, rather he noted the existence of "poverty in the midst of plenty" caused by the impact of excess demand for liquidity on interest rates. This would produce a scarcity of demand for labour and unemployment. But, this very same factor was also at the root of the inequitable distribution of income, because liquidity protected the investor, while it produced loss of income for the labourer. Thus, the same factor that produces unemployment for Keynes also produces inequality: the key to both insufficient demand for labour and inequality could thus be found in the fear of loss on assets and the fear of default on loans. In short, the faults were primarily caused by the behavior of creditors thus his call for the euthanasia of the rentier, and a more active role of government in providing liquidity, either through government financial institutions or through high levels of government spending which would calm the demand for liquidity by generating higher profitability.

While Keynes was writing in the context of what was then the most developed economy in the world. Yet, economies in the process of development exhibit the very same faults of unemployment and inequitable distribution of income, and they are caused by the same factors. Developing economies are usually characterized by the dominant role of agricultural production. In her analysis of full employment of a developed economy Joan Robinson (1936) argued that there is "disguised unemployment", or "underemployment" of labour whenever it is possible to expand output without reducing consumption per head. This concept was adapted to developing countries, and to employment conditions in agriculture by an Indian economist V.R.K.V. Rao (1952) who noted that it would be possible to remove labour from peasant production without reducing the production of food. Neoclassical economists took up this idea as a zero or negative marginal product of labour in agricultural production. Thus the main problem facing developing countries was how to use this exhuberant labour force. Since there is a limit to the amount of food that can be consumed, improving conditions would require an alternative to increasing investment and employment in agriculture.

The most widely accepted solution is creation of a manufacturing sector to provide employment for the disguised unemployed agriculture. Given a higher rate of technical progress, transferring redundant labour from agriculture to industry increases average incomes and provides self-generating expansion of demand for manufacturing output. This

\footnotetext{
* Draft of remarks to 22nd Congresso Brasileiro de Economia, sponsored by the Conselho Regional de Economia de Minas Gerais (Corecon-MG) and the Conselho Federal de Economia (Cofecon), Belo Horizonte, September, 2017.

† Levy Economics Institute, kregel@levy.org.
} 
increasing scale of production allows for a further increase in output per man and income growth. The general problem facing developing countries is then the search for alternative sources of employment in activities with higher productivity and the potential for technical progress outside the agricultural sector. Note that this is also the major problem facing industrialised economies for rising output per man due to technical progress in manufacturing will continuously create exuberant labour and the need for alternative sources of employment. Technical progress is thus a two-edged sword - it provides for alternative sources of employment with higher productivity at the same time as it reduces the amount of labour that can be absorbed, making development a never-ending search for new activities for workers displaced by technical progress. Of course, this is not a new idea, it had already been raised by Ricardo in his famous chapter "On Machinery".

But, the more pressing problem facing developing countries is how to finance the creation of these alternative sectors to absorb the unemployment created by technical progress. The traditional response is to argue that there is a barrier caused by the failure of domestic incomes to generate the savings required to purchase the foreign capital goods and technology necessary to build a manufacturing base. And the tendency for the terms of trade to decline eliminates the possibility of exporting excess agricultural output from increasing employment in that sector. The only solution would appear to be to rely on opening domestic markets to foreign lenders and producers to rely on foreign portfolio or direct investment. This is supported by the idea that the low marginal productivity of labour is accompanied by high marginal productivity of capital, indicating an overall benefit from shifting savings and investment from developed to developing countries.

This approach embodies two errors. The first is that the marginal productivity of capital is high in developing countries, aside from the theoretical and empirical difficulties in even defining the concept. The generally accepted results of the Cambridge capital theory debates suggest that the whole idea is meaningless, plus the real business cycle theorists have now adopted the view of the early Keynesian development theorists that reality is just the reverse with marginal productivity of capital higher in developed than developing countries.

The second is the representation of the financial system to support these capital flows as a simple intermediary that provides for the allocation of household savings to investors seeking to expand into new activities. And as noted, at the international level this intermediation is driven by an arbitrage process which supposed to transmit finance from low rate of return, capital intensive, developed economies to high rate of return, capital scarce, developing countries.

But, as Schumpeter (1912) pointed out in his Theory of Economic Development, echoing the work of economists such as Bendixen (1908), L. Albert Hahn (1920), von Mises (1912), Hayek (1933), Hawtrey (1919), Robertson (1922) and Keynes (1930), amongst others, banks have an unlimited capacity to create purchasing power to finance capital accumulation. For these economists, banks were considered "dealers" in debts and provide the financing of production by granting borrowers credits in the form of liabilities that served as a means of liquidating their liabilities, what we would today call "means of payment." This modern parlance reflects the view that bank lending to entrepreneurs takes the form of creating deposit liabilities that producers use as means of payment to purchase labour and other inputs which finance development. These economists thus concluded that saving was not the relevant constraint on investment, but rather the existence of a financial system to finance investment.

In this view, the creation of a domestic financial system is a prerequisite for the development of alternative sources of employment via creation of a manufacturing sector and 
overcome any constraint to this process posed by a scarcity of domestic or foreign savings. (See Kregel 2016) But, Keynes warns that the successful process of development finance by a strong domestic financial system may still be characterized by unemployment and income inequality. While this cannot be due to any lack of domestic saving to finance new sources of employment, it will still be the case that the instability of the financial system may limit the ability of entrepreneurs or governments to finance a domestic manufacturing system since the stability of the system depends on investments being financed are capable of producing sufficient returns to repay the lending.

This constraint on the ability of the domestic financial system to provide for employment prospects and a more equitable distribution of income can be seen in what Hyman Minsky (1995) referred to as the need for the financial system to serve "Two Masters" - the need to provide a safe and secure means of payment, on the one hand, and to finance inherently risky investments in new development projects to expand employment, some of which will inevitably fail. The first "Master" is represented by the bank deposit liabilities used as means of payment, which are created by bank acceptance of claims on the returns to the risky investments of entrepreneurs. But the value of these liabilities respond to the second "Master".

Since it is an imperative of balance sheets that assets must equal liabilities, any nonrealisation of the expected returns to the risky investments represented in the second Master will by definition impair the value of the means of payment liabilities of the first Master. The objective of financial stability means that Master 1 must always be satisfied; there must never be losses imposed on holders of these deposit liabilities. The problem is thus not only the creation of a domestic financial system to finance investment, but who will bear the inevitable losses on uncertain, risky investment required to finance the buildup of the manufacturing sector to provide the absorption of underemployed agricultural labour. If the financial system is to be perfectly safe and secure the success of the financial system in development financing will depend on finding the means to meet the risks inherent in Master 2 or by placing limits on the powers of Master 2 to menace Master 1. (see Kregel, 2013)

This limitation usually takes the form of what is called "prudential regulation" on the financial system. Prudential means the equivalent of "safe and sensible" behavior imposed on banks. It can involve limitations on the asset side or the liability side of financial institutions' balance sheets. On the asset side are restrictions on the type of assets banks can acquire, called "directed" lending. For example, mortgages were long forbidden to banks as part of the second Master requirement. There were also positive requirements and restrictions placed on the holdings of liquid assets or claims on the central bank.

Deposit insurance, which is a form of guarantee on the value of bank liabilities is a means of guaranteeing the objectives of Master 1. Requiring banks to hold owners' equity to absorb losses on Master 2 assets is also a common regulatory requirement, including setting ratios of bank capital to risk-weighted assets and/or liabilities, or bank leverage. Finally, the creation of a central bank that acts as a lender of last resort to provide validation of banks' assets provides a systemic form of stability to the financial system.

While these measures are designed to limit the potential losses from the unlimited ability to create purchasing power, and thus are meant to avoid idiosyncratic losses due to management failures at individual institutions, they do not deal directly with the question of who bears the inevitable systemic risk of the Master 2 losses that is inherent in the development process. Indeed, if these risks are to be an important part of the development process they are to be encouraged, not eliminated. 
Thus, while Schumpeter emphasised, the importance of the financial system as the engine of economic development because of its unlimited ability to create purchasing power independently of any savings constraint, the survival and stability of this system depends on the avoidance of losses that should be encouraged as inherent in the development process. In a system of private risk bearing loss should be borne by the investor, but as Keynes pointed out, it is the avoidance of this risk that leads to the refuge of liquidity and the failure of investment to expand to provide growth of employment. It is this that makes finance for development scarce and produces unemployment. But, it is also the case that the defence of the stability of the financial system will be to attempt to stabilize asset prices to avoid impairment of liabilities used as means of payment. This means that there will be an asymmetric distribution of losses which favours creditors at the expense of labour.

Much has been written about the private nature of profits and the socialization of losses in a free enterprise system, but as long as the system operates on the financing of investment by private financial institutions under the constraint of financial stability with prudential measures devoted to stabilizing asset prices this must always be the case. By default, it is thus the need to limit risk, and to insure financial stability that ensures that finance will be insufficient to provide for the required levels of employment and at the same time provide a protection to bankers and investors exposure to risk. The implication is that it will be labour that bears the risks, in the form of unemployment and an absence of asset accumulation that provides an explanation of the inherent inequality of income and wealth in a privately financed development system.

This means that wealth will tend to be accumulated by those individuals who have access to the financial system and in the financial system itself since stability measures will be focused on stabilization of asset prices. Since access to finance is in general linked to either good credit performance or the existence of collateral, this means that those who are responsible for investment will have an increasing share of the wealth that is created by the development process. And those who live on employment will have a declining share since in the case of unsuccessful investments labour loses its earning power, while stabilization measures limit the financial losses for investors and financial institutions. Note that this reasoning is just the opposite of the position that argues that those who provide the saving for investment will have an increasing share of wealth because they bear the risk and uncertainty of investment in new development activities.

The question facing developing countries is then the design of an alternative financial system which provides a mechanism to support the losses inherent in development financing at the same time as it insures a more equitable distribution of the fruits of investment and innovation. As noted above, the conditions of financial stability are usually sought through prudential regulation which is intended to protect the primarily non-investing classes holding financial sector liabilities as a means of payment. But, paradoxically, it is precisely this protection that insulates financial institutions and investors from loss and preserves their wealth. If the payment liabilities are protected, then the bank's assets are protected, and this means that the losses born by the issuers of those liabilities will be also be protected.

There seem to be two alternatives. One would be to provide the same guarantee to labour as provided to investment. Minsky has proposed an employer of last resort program to guarantee work to all who are willing and able. This would provide a minimum stability to labour incomes in the same way stability to banks' assets and liabilities are provided by prudential regulation and crisis intervention to support asset prices. Something like a central jobs bank to parallel the Central Bank. Indeed, it is widely accepted that the best remedy for poverty and income inequality alleviation is a high level of employment. This would provide a more equitable burden and support of the risks of new investments. 
Another alternative proposed by Minsky would be to replace insurance funds for bank liabilities with a full government guarantee of deposits, or alternatively, to replace deposit insurance with a system of insuring bank assets to encourage more risky lending without jeopardising the use of bank liabilities as means of payment.

Of course, the entire problem created by financial stability would be resolved by the creation of government development banks to finance risky investment and provide a safe and secure means of payment while the risks would be carried by the federal government budget. This would avoid the procyclical nature of private financing caused by the rush to liquidity in the face of declining outlook on future returns on assets. A more radical alternative, but one which governments always discover in the process of financing a major war - government control of the financial system since banks are essentially redundant to this process of mobilizing resources for destruction - unfortunately these lessons are forgot when mobilizing resources for development purposes.

It is interesting that Brazil, in its early development experience, has been in the forefront of this type of approach, and with a substantial degree of success. However, recent events have suggested that the importance of a clear recognition of the impact of the distribution of risk on the distribution of income has been lost to sight. First, the decision to apply the same prudential regulations to private financial institutions and development banks represents an internal contradiction, or at best a double counting for the first Master is served by both prudential regulation and by the role of the government budget in support of the bank.

Secondly, the recent imposition of requirements on the configuration of the government budget means that the rational support of risk-taking to be spread over the entire economy is diminished or eliminated, since the losses would be covered in the government budget. Indeed, it is ironic that the rational use of this mechanism of using the government budget to support lending for development employed in the aftermath of the recent Great Recession has led to recrimination and political disruption when this is precisely the role that government should play in intermediating risk.

Finally, the idea that seems to be spreading in response to this crisis to promote the substitution of development financing via private sector institutions in place of government development banks means restoring the inequitable sharing of risk of development finance, promoting instability and protecting finance at the expense of labour, and the inevitable worsening of the distribution of income. Private sector financial markets do not have a good record of providing finance to development investment at levels and rates that would ensure expanding employment, and there is no reason to believe that this will change if the role of development banks is minimized. As liquidity preference becomes the dominant decision variable for investment, Brazil will be back to the problems that Keynes originally analysed in the General Theory, with the addition of the prudential requirements that will aggravate the instability of the growth process, even in the presence of a fully developed domestic financial system, and tilt social support in favour of finance at the expense of labour.

\section{References}

Bendixen, F. (1908) Das Wesen des Geldes Duncker \& Humblot GmbH

Hahn, L. A. (2015) [1920] Economic Theory of Bank Credit, Clemens Matt and Harald Hagemann, editors, Oxford: University Press.

Hawtrey, R.G. (1919) Currency and Credit, London: Longmans Green, 
Hayek, F.A. (1933) Monetary Theory and the Trade Cycle, London: Jonathan Cape.

Keynes, J.M. 1936. General Theory of Employment, Interest and Money. London: Macmillan

Kregel, J. (2013) "Trying to Serve Two Masters: The Dilemma of Financial Regulation." In B. Z. Cynamon, S. M. Fazzari, and M. Setterfield, eds. After the Great Recession: The Struggle for Economic Recovery and Growth. Cambridge: Cambridge University Press.

J. Kregel, (2106) "The Effective Demand Approach to Economic Development," in Rainer Kattel, Erik Reinert, and Jayati Ghosh, Elgar Handbook of Economic Development.

Minsky, H. P. (1995) "Would Repeal of the Glass Steagall Act Benefit the US Economy" in Hyman P. Minsky Archive. Paper 60

http://digitalcommons.bard.edu/hm_archive/60

Mises, L. $(1953,1912)$ The Theory Of Money And Credit, New edition, enlarged, translated from the German by H. E. Batson, New Haven: Yale University Press/

Rao, V.K.R.V. (1952) 'Investment, Income and the Multiplier in an Underdeveloped Economy', Indian Economic Review 1(1), 55-67.

Robertson, D. H. (1922) Money, Cambridge Economic Handbooks.

Robinson, J. 1936. 'Disguised Unemployment', Economic Journal 46(182), 225-237.

Schumpeter, Joseph A. (1961) [1912]. The Theory of Economic Development. Oxford: Oxford University Press.

Ricardo, D. (1821) On the Principles of Political Economy and Taxation, London: John Murray, (third edition) 